\title{
Population size, breeding performance and habitat use of the Black-winged Pratincole Glareola nordmanni
}

\author{
JOHANNES KAMP, MAXIM A. KOSHKIN and ROBERT D. SHELDON
}

\section{Summary}

The population of the Black-winged Pratincole Glareola nordmanni has declined significantly during the course of the $20^{\text {th }}$ century, resulting in a classification as 'Near Threatened' and 'Endangered' in the Global and European Red Data Books, respectively. Reasons for the decline are largely unknown due to a lack of information on the breeding ecology of the species. We studied breeding performance and habitat use of the Black-winged Pratincole in two areas in Kazakhstan and evaluated a new world population estimate. Colony size ranged from two to 180 pairs and differed significantly between the study areas. Mean breeding success was $1.30 \pm 0.16$ (mean \pm SE) fledged chicks per breeding pair in Central Kazakhstan, and $0.59 \pm 0.13$ (mean \pm SE) fledged chicks per breeding pair in NE Kazakhstan. Habitat types preferred were intensively grazed natural steppe, abandoned and fallow fields, shores of freshwater and brackish lakes and solonchaks (salt pans). Factors influencing habitat selection were quantified the first time for this species: the probability of occurrence of breeding colonies was highest near human settlements, within $3 \mathrm{~km}$ of open water and where sward heights were low or intermediate, indicating a reliance on heavy grazing and water.

Using data from six surveys across the whole breeding range, we calculated a new world population estimate of $76,000-95,000$ breeding pairs, which is substantially higher than previous estimates. We discuss colony size, habitat use and population trends in the light of changing landscape conditions in the steppe zone and suggest an increase in habitat available to Blackwinged Pratincole due to an increase in the area of fallow fields and a change in grazing regimes since the collapse of the Soviet Union in 1991.

\section{Introduction}

The Black-winged Pratincole Glareola nordmanni is a breeding endemic of the Eurasian steppe zone. Its breeding distribution is largely restricted to Southern Russia and Kazakhstan, with single pairs or small colonies in Ukraine, Belarus, Armenia, Azerbaijan, Romania and Hungary (Belik and Lebedeva 2004; Figure 1). The species winters in southern Africa, mainly in Botswana and the Republic of South Africa. Due to a historical population decline lasting at least until 2000, the species has recently been globally up-listed to 'Near Threatened' (Birdlife International 2007), with an estimated population of 29,000-45,000 mature individuals. In the European Red Data Book, the Black-winged Pratincole is listed as 'Endangered' (Birdlife International 2004) due to dramatic declines in European Russia and the almost complete loss of the Ukrainian population (Belik et al. 2000, Belik 2004, Belik and Lebedeva 2004).

Around 1850, Black-winged Pratincole population size was significantly larger than today, and post-breeding flocks even in the smaller European part of the breeding range numbered hundreds of thousands of birds (Kessler 1851). Declines have been reported from all over the breeding 
range since 1910, and the European breeding population declined by $40-60 \%$ after the collapse of the Soviet Union (Belik 2004, Belik and Lebedeva 2004). A contraction at the western part of the range was observed, leading to a possible extinction of Black-winged Pratincole in Ukraine. In central southern Russia, the results of large scale surveys point to a slight to pronounced increase in numbers since the beginning of the 1990s (Karyakin and Koslov 1999, Korshikov 2002). Trends in Kazakhstan, the stronghold of the species, have never been quantified, but numbers appear to have increased slightly between 1998 and 2007 (A.V. Koshkin pers. comm. 2007, A.O. Solomatin pers. comm. 2007).

Factors behind population declines are poorly studied. Belik and Lebedeva (2004) presented an overview, including the following main factors in the breeding areas: i) ploughing of steppe (more than 25 million ha in Kazakhstan) resulting in habitat loss and low breeding success in colonies on arable fields, ii) trampling of clutches and chicks due to lower mobility and stronger concentration of livestock compared to previous times, iii) higher predation rates by increasing numbers of corvids, and iv) climate change with increasing frequencies of extreme weather (e.g. hailstorms) and droughts.

Information on habitat use of the Black-winged Pratincole is largely anecdotal or based on low sample sizes. The availability of freshwater for drinking, short vegetation, and the presence of livestock were mentioned by a number of authors (Koshelev 1983, Samorodov 1986, Karyakin \& Koslov 1999, Korshikov 2002, Belik 2004, Belik and Lebedeva 2004). In European Russia, where large areas of natural steppe are ploughed up, Black-winged Pratincoles are known to nest in significant numbers both on arable (Moseikin et al. 2004) and on fallow and abandoned (hereafter referred to as fallow only) fields (Moseikin et al. 2004, L. Malovichko pers. comm. 2007). Livestock grazing seems to be important for the species, because it creates short swards available for nesting and might improve food supply, as coprophagous insects are attracted by dung.

As published information on population numbers, habitat use and breeding success is limited, the Single Species Action Plan for the species (Belik and Lebedeva 2004, see also BirdLife International 2007) stresses an urgent need for research on population ecology and dynamics. Here we present quantitative data on Black-winged Pratincole abundance, breeding performance and habitat use from two study areas in Kazakhstan. Our results might serve as a first step to implement broader, conservation-orientated research.

\section{Study areas}

Fieldwork was carried out during the breeding season 2006 in proximity to Lake Tengiz, $120 \mathrm{~km}$ SW of Astana, Kazakhstan (Figure 1; cf. also Schielzeth et al. 2008). The village of Korgalzhyn constitutes the largest settlement. The study area covered approximately $200 \mathrm{~km} \mathrm{x} 150 \mathrm{~km}$ $\left(30,000 \mathrm{~km}^{2}\right)$ and stretched between $49^{\circ} 4 \mathrm{O}^{\prime}-50^{\circ} 55^{\prime} \mathrm{N}$ and $68^{\circ} 38^{\prime}-70^{\circ} 59^{\prime} \mathrm{E}$. In 2007, approximately $12,000 \mathrm{~km}^{2}$ were surveyed in Pavlodar region in NE Kazakhstan within a study area situated along the lower Irtysh river between the settlement Akku (= Lebyazhe, $c \cdot 51^{\circ} 28^{\prime} \mathrm{N} /$ $77^{\circ} 46^{\prime} \mathrm{N}$ ) and the Russian border at $c .53^{\circ} 47^{\prime} \mathrm{N} / 75^{\circ} \mathrm{O} 3^{\prime} \mathrm{E}$ (Figure 1 ).

The Korgalzhyn study area (Central Kazakhstan) is dominated by flat short-grass steppe and (mostly fallow) cereal fields in the north and hilly semi desert in the south. The area is characterised by many fresh and saline lakes (the latter known as solonchaks), the largest being the saline Lake Tengiz with an area of approximately $1,380 \mathrm{~km}^{2}$. It is a highly important breeding and stop-over site for waterbirds (Schielzeth et al. 2008).

The Lower Irtysh study area is dominated by the Irtysh River. The river has never been straightened, and the floodplain ( $16 \mathrm{~km}$ wide) is inundated for ${ }^{16-43}$ days per year (A.O. Solomatin pers. comm. 2007), chiefly in May. Oxbow lakes, extensive reeds and willow thickets are interspersed with late-mown hay meadows. The adjacent landscape on both sides of the river is characterised by herb-rich tall-grass steppe and small birch forests.

In both study areas, the character of steppe vegetation is strongly influenced by domestic grazing with livestock concentrated around human settlements. This leads to an unequal grazing 

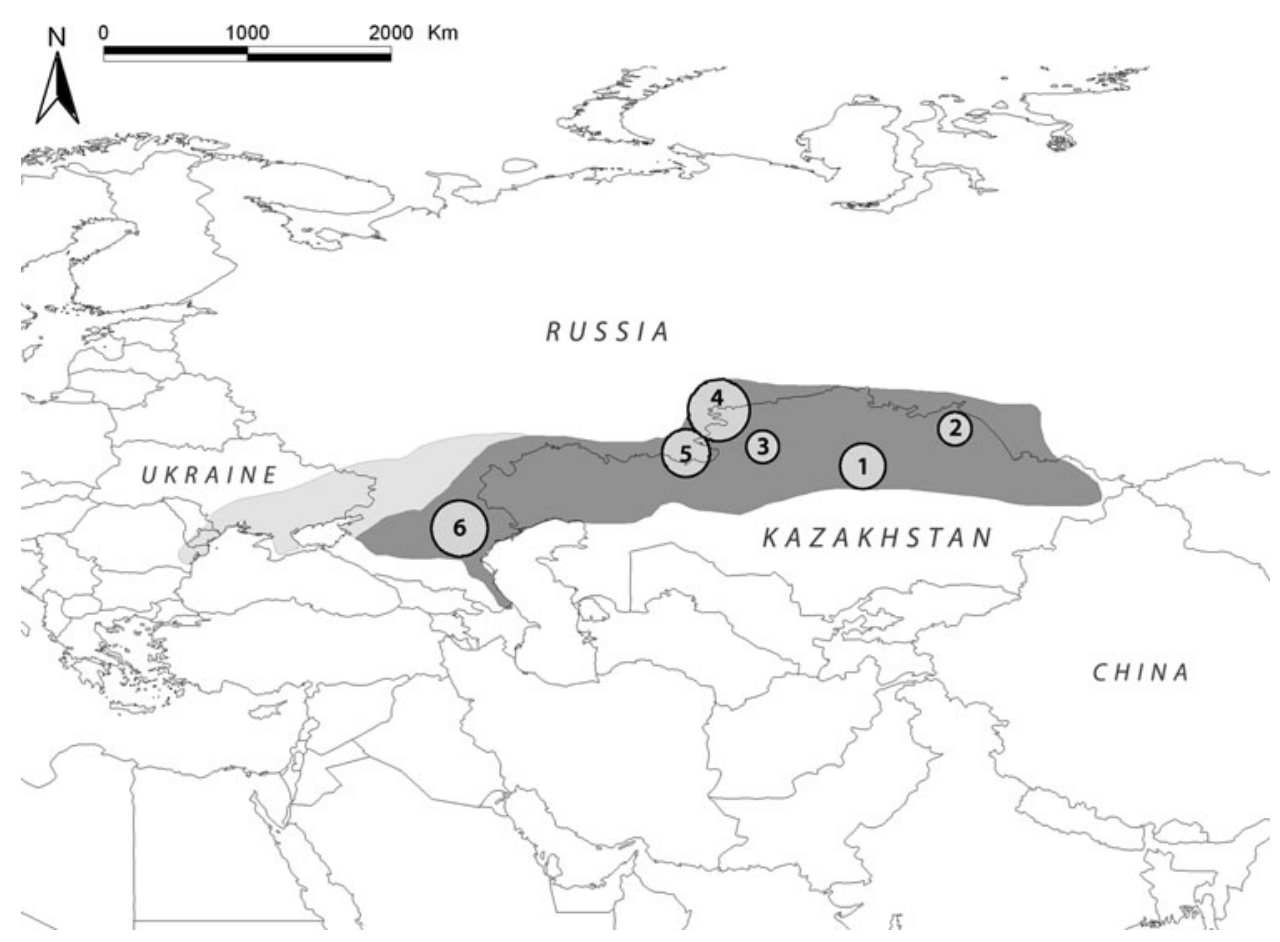

Figure 1. Location of the Korgalzhyn and Lower Irtysh study areas (nos. 1-2) and areas of further surveys considered for the population estimate (nos. 3-6) within Kazakhstan and Russia. Numbers correspond to those in Table 2. Circle size is proportional to the area of the region surveyed. The dark grey area shows the current breeding distribution of Black-winged Pratincole, across the light grey area, the species is considered extinct.

pressure resulting in dense, tall stands of fescue Festuca sulcata and feather grass Stipa lessingiana where grazing intensity is low, and wormwood Artemisia spp. dominated short swards where livestock is concentrated.

\section{Methods}

\section{Sampling design and data recording}

The Korgalzhyn study area was surveyed for Black-winged Pratincoles from the end of April to the end of July 2006, the Lower Irtysh study area from the end of April to the end of July 2007. We surveyed all previously known breeding sites of Black-winged Pratincole, on which information was available from local databases and expert communication (Schielzeth et al. 2008, V.V. Khrokov 2007, in litt.), as well as all wetland sites similar to habitat used in previous years (freshwater lakes with open shores, solonchaks). Furthermore, we surveyed large areas of fallow fields as well as pristine steppe. Due to the huge size of the study area, this was done from a vehicle. We partly stopped at vantage points and surveyed the area using a telescope, partly watched out for pratincoles driving transects with low speed (c. 20-30 $\left.\mathrm{km} \mathrm{hr}^{-1}\right)$. The total length of survey transects driven across the areas was approximately $1,200 \mathrm{~km}$ in 2006 and $700 \mathrm{~km}$ in 2007. Habitat obviously unsuitable for breeding pratincoles (such as birch forest in the Lower 
Irtysh area, reeds and open water) was not surveyed. Black-winged Pratincoles often hunt in flight near breeding colonies and are thus very obvious over large distances, hence car-based surveys are regarded as a suitable method. Using telescopes, flying pratincoles can be identified at even larger distances, in good light conditions up to several kilometres.

We estimate that combining the approaches described above we were able to cover approximately $75 \%$ and $80 \%$ of the area suitable for breeding pratincoles. The remainder comprises mainly complexes of contiguous wheat fields, which often cover several thousand hectares, and are inaccessible to normal vehicles. Due to the rather cursory nature of the car-based surveys, all numbers presented here should be considered as minimum figures.

When a colony was located, the number of adults was recorded, combining repeated counts of flying and sitting/incubating birds. Most colonies were subsequently visited every 3-10 days until chicks fledged. As the sex ratio within the colonies was observed to be mostly even (sexes can be separated by plumage differences and size when seen together and birds remain paired during incubation), the maximum number of birds present in a colony during the nest initiation period was divided by two and the resulting number used as an approximation to the number of breeding pairs. A colony was defined when either incubating birds or chicks were seen, or nests were found.

To estimate breeding success, colonies were visited when the chicks had just fledged and still did not fly well enough to cover large distances. Recently fledged juveniles tend to gather in dense post-breeding flocks at the colony site, accompanied by alert adults flying around them in a loose group. Overall breeding success per pair was calculated by dividing the number of fledged chicks by the number of estimated breeding pairs. This could be done only for some colonies, because in other colonies juveniles had already started to disperse from the colony site.

To analyze differences in habitat selection between the study areas, main terrestrial habitat types were defined using our own classification. Factors influencing breeding habitat selection were studied on the landscape scale in the Korgalzhyn study area in 2006 using a presenceabsence habitat modelling approach. The sample unit was the single breeding colony. A colony was defined as an aggregation of breeding pairs at least $3 \mathrm{~km}$ apart from the next breeding incidence to avoid strong autocorrelation. Habitat parameters to be examined for an influence on Black-winged Pratincole breeding habitat selection were chosen on the basis of published information suggesting that especially the availability of water and low vegetation influence habitat selection (Belik 2004). Parameters recorded included 'maximum vegetation height' and 'distance to nearest permanent water feature'. As our own observations in the study areas from previous years suggested that the presence of livestock is an important factor as well, the variable 'distance to nearest settlement' was additionally included. This has been proved a strong correlate of both dung densities and livestock abundance in the Korgalzhyn region (Spearman's $r>0.9$; J.K. 2006 unpubl. data). Within the colonies, all parameters were measured at a nest site in the centre of the colony. This was considered representative for the whole colony. These colony points representing 'presence' were compared with points randomly selected across one third of the study area (containing the whole range of habitats and covering the whole latitudinal gradient). Random points were automatically defined on a map using a random point generator in ArcView 3.2a (Jenness 2005). Effective sample size was limited by the scattered distribution of the colonies throughout the study area. Thirty-five colonies were available for variable sampling and 109 random points were generated to collect absence data, thus prevalence was higher than the minimum of $20 \%$ suggested by Bonn and Schröder (2001).

Vegetation height $(\mathrm{mm})$ was recorded in the field using a simple folding rule, distance values were calculated in ArcView 3.2a. Vegetation height was recorded in the period 25 May-16 June 2006. Since vegetation growth within the recording period would limit comparability of single presence/absence points and model quality, vegetation height measurements were repeated at 60 points chosen randomly out of the predetermined presences and absences once in Korgalzhyn region. Vegetation height did not differ significantly between measurements taken on 21 May and 5 June 2006 (Wilcoxon test: $Z_{67}=-1.3, P=0.175$ ). 


\section{Data analysis}

The proportion of every habitat type within the study area was estimated from Landsat 7 ETM+ scenes representing habitat availability, and breeding habitat selectivity was assessed using the Jacobs preference index (Jacobs 1974).

To analyse habitat selection, binary logistic regression was used (Hosmer and Lemeshow 2000). A univariate analysis was conducted first for all variables separately to test for correlation with presence or absence as suggested by Hosmer and Lemeshow (2000) and in order to avoid spurious inclusion of variables in a multivariate model. We tested correlations between predictors to avoid multicollinearity (Graham 2003), but since correlations were generally weak (all $r_{s}<0.5$ ) we included all predictors in a full model. We used a stepwise backward procedure (critical $p$-value $p_{\text {out }}=0.10$ for variable removal, likelihood-ratio test) for model simplification. All models were fitted in SPSS 15.O. Before processing variables in multivariate models, the shape of the environmental relationship was determined, i.e. the pattern of each variable's response to environmental factors. This has often been neglected, but is a crucial factor when using statistical models to predict species abundance and distribution (Austin 2002). Relationships can be either sigmoid (with positive or negative characteristic) or unimodal ('bell-shaped' or 'bowl-shaped'). Whether a relationship was sigmoid or unimodal was tested by assessing which variant provided the best fit to the data by the level of significance. If both relationships were significant, the one with the stronger response (according to Nagelkerke's $R^{2}$, Strauss and Biedermann 2006) was chosen.

To assess the predictive power of the final models, several measures of model quality were calculated: i) Nagelkerke's $R^{2}$, which describes model calibration and refinement (Nagelkerke 1991), ii) AUC (area under the receiver operating characteristic, ROC), which describes discrimination (Hanley 1982, McNeil and Hanley 1984), and iii) Cohen's Kappa, which describes discriminative power prevalence-independent (Manel et al. 2001). All models were internally validated using bootstrapping (Manly 2001) with 300 iterations. Measures for model quality and bootstraps were calculated using the SPlus 6.1 statistical package.

We calculated a new world population estimate using the large-scale breeding densities derived from our study and from other recent surveys across the entire distribution range of the species. A minimum and maximum density value $(\hat{D})$ for each survey (equation 1 ) was calculated according to the minimum and maximum number of breeding pairs $\left(n_{\text {pairs }}\right)$ found in area $A$. Minimum numbers refer to counted pairs, maximum numbers refer to estimated maximum numbers.

$$
\frac{\hat{D}=n_{\text {pairs }}}{A}
$$

Subsequently, the mean minimum and maximum density per area were averaged for all surveys $\left(\hat{D}_{\text {mean }}\right.$, equation 2$)$.

$$
\hat{D}_{\text {mean }}=\frac{\sum_{k=1}^{n} \hat{D}_{k}}{n_{\text {surveys }}}
$$

To achieve a new estimate for the world population $\left(N_{\text {pairs.tot }}\right)$, we multiplied this density by the range of the current distribution of the Black-winged Pratincole $\left(A_{t o t}\right)$, which was estimated rather conservatively at $1,922,311 \mathrm{~km}^{2}$ (GIS data) after reviewing the relevant literature (J.K. 2007 unpubl. data) and considering the species as extinct in Ukraine (BirdLife International 2004): 


$$
\mathrm{N}_{\text {pairs.tot }}=\hat{D}_{\text {mean }} * A_{\text {tot }} .
$$

We consider this way of extrapolation to be sound, because i) large scale population densities from six studies were fairly similar (cf. Table 2), ii) the area covered by all surveys combined was large $\left(200,000 \mathrm{~km}^{2}\right.$ or approximately $10 \%$ of the species' distribution area), iii) the study areas were distributed across the whole range of the species and included marginal populations.

\section{Results}

\section{Local population numbers and densities}

In total, 1,207 breeding pairs in 35 colonies were recorded throughout the Korgalzhyn study area and a total of 627 breeding pairs in 41 colonies throughout the Lower Irtysh study area. Since only about $75 \%$ and $80 \%$ respectively of the areas could be covered, the population size was estimated to reach c. 1,500 pairs in the Korgalzhyn area and c. 785 pairs in the Lower Irtysh area. This equals a large scale population density of 3.8 (survey count) to 4.7 (estimate) breeding pairs per $100 \mathrm{~km}^{-2}$ for the Korgalzhyn area and 5.2 to 6.4 breeding pairs per $100 \mathrm{~km}^{-2}$ for the Lower Irtysh area.

\section{Colony size}

Colony size was significantly smaller in the Lower Irtysh area with 1-70 breeding pairs per colony (15.3 \pm 19.1 , mean \pm SD) compared to the Korgalzhyn study area with 2-180 pairs per colony $\left(34.5 \pm 37.7\right.$, mean $\pm \mathrm{SD}$ ) (Mann-Whitney U-Test: $\left.Z_{76}=-2.9, P=0.004\right)$. Most colonies consisted of $1-10$ pairs in both areas, while colonies with more than 1oo pairs $(n=2)$ were found exclusively in the Korgalzhyn area (Figure 2).

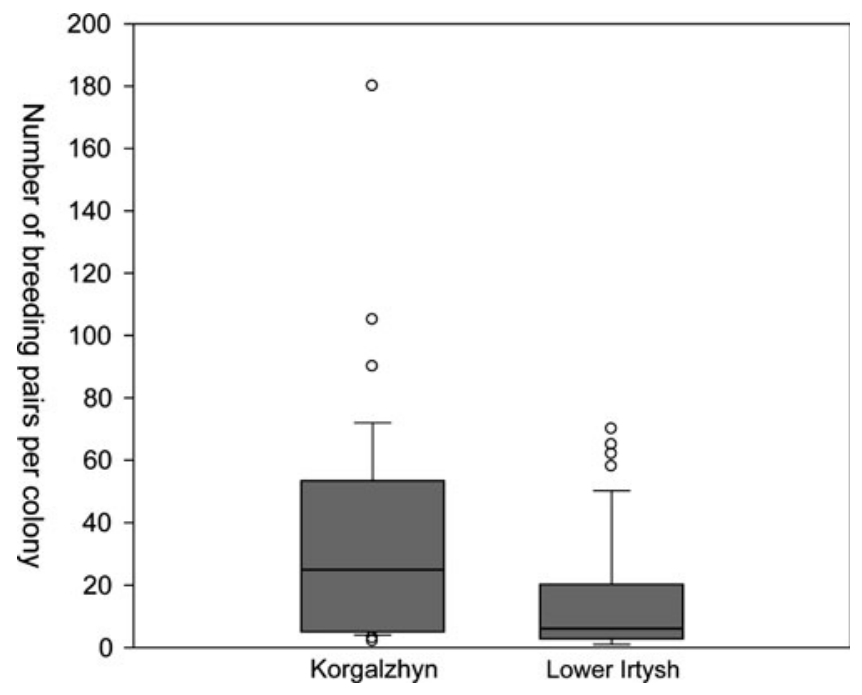

Figure 2. Comparison of Black-winged Pratincole colony size (number of breeding pairs per colony) in both study areas. 


\section{Breeding phenology}

First (already paired) birds were seen on 28 April 2006 in the Korgalzhyn area and on 7 May 2007 in the Lower Irtysh area. First nests were found on 4 May and 14 May respectively. As they mostly contained incomplete clutches of one or two eggs, they were considered as fresh. Hence, these dates are probably close to the overall start of the egg-laying period. There was no first hatching date recorded for Korgalzhyn region. In the Lower Irtysh region, first chicks hatched on 6 June 2007 ( $n=12$ nests). First fledged chicks were observed on 1 July 2006 in Korgalzhyn, and on 5 July 2007 in the Lower Irtysh study area. Clutch size was $3.41 \pm 0.51$ (mean \pm SD, $n=12$ nests) in the Lower Irtysh region.

\section{Breeding success}

Breeding success was $1.30 \pm 0.16$ (mean $\pm \mathrm{SE}$, range $0.82-1.78, n=6$ colonies) fledged juveniles per pair in the Korgalzhyn study area and $0.59 \pm 0.13$ fledged juveniles per pair (mean $\pm \mathrm{SE}$, range $0.00-2.33, n=20$ colonies) in the Lower Irtysh region. Breeding success was significantly lower in colonies of the Lower Irtysh study area compared to that of the Korgalzhyn area $(t=$ 3.8, $d f=24, P=0.005)$, but since the two sites were sampled in different years, site and year effects cannot be separated. Around several empty scrapes, droppings of foxes and hedgehogs were found, suggesting that predation by these species was an important cause for clutch loss. Trampling by livestock was observed only once, but there was evidence from eggshell remains that sheep flocks in the Lower Irtysh study area trampled further nests in 2007.

\section{Habitat use and selection}

In the Korgalzhyn study area, the majority of colonies were located at muddy shores of freshwater and slightly saline lakes (23\% of all colonies) and dried-out solonchaks (salt pans) with a dense cover of Salicornia spp. (49\%). In the Lower Irtysh area, most colonies were found on intensively grazed swards on natural steppe $(39 \%)$ and fallow arable fields $(24 \%)$ dominated either by Wormwood Artemisia sp. or Fescue Festuca sp. Breeding on recently sown arable fields and burnt steppe was recorded in the Lower Irtysh region only. Intensively grazed steppe, shores of freshwater and brackish lakes, and solonchaks were the preferred habitat types in both areas (Figure 3). There was a stronger preference for wetland habitats in the Korgalzhyn region, whereas in the Lower Irtysh study area fallow and grassland habitat were slightly preferred. Grazing livestock was present at all colonies (usually throughout the breeding season, but in some cases at the beginning of the breeding season only).

Maximum vegetation height, distance to nearest village and distance to nearest permanent water feature all differed significantly between colonies and random points (likelihood-ratio test, $P<$ o.oo1, Table 1), suggesting that colonies in the Korgalzhyn area in 2006 were not randomly sited with respect to these three variables. In a second step, we fitted a multivariate model including all three predictors. Diagnostic statistics showed that the model fitted the data well and internal validation did not significantly reduce model quality (Nagelkerke's $R^{2}=0.906$, AUC $=0.988$, Cohen's $\kappa=0.926$, bootstrapped model). $97.2 \%$ of all presence- and absence-points were classified correctly. Occurrence probability decreased with increasing distance to settlements (including cattle brigades) and permanent water features. Maximum vegetation height strongly influenced distribution patterns as well, with an occurrence probability peak (i.e. habitat optimum) reached at $\mathrm{h} \approx 50 \mathrm{~mm}$ (Figure 4 ).

\section{World population}

Based on large-scale breeding density estimates from this study and recent literature data (Table 2, Figure 1), we extrapolated a new world population estimate of $76,416-95,143$ breeding pairs, approximated to $76,000-95,000$ breeding pairs. 


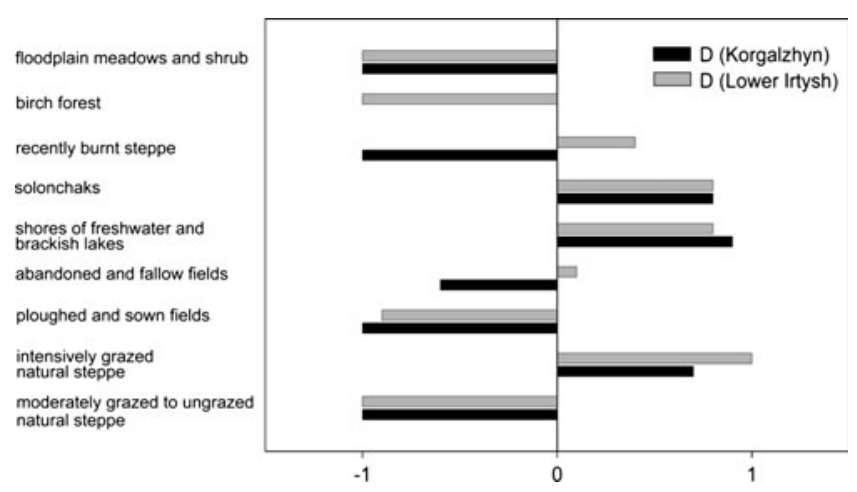

Figure 3. Comparison of breeding habitat use of Black-winged Pratincole in both study areas described by the Jacobs preference index $D$. Values $<$ o indicate an avoidance of the habitat type referred to (-1: complete avoidance), those $>0$ indicate a preference for the habitat type referred to.

\section{Discussion}

\section{Colony size and breeding performance}

The colony sizes ascertained for the study areas considered here are fairly similar to the range cited in the literature. Across the southern Russian breeding grounds, most colonies hold 3-20 pairs, with larger ones up to 150 pairs (Koshelev 1983, Davygora et al. 1992, Karyakin and Koslov 1999, Korshikov 2002, Belik 2004, L. Malovichko in litt. 2007). The largest colonies found in recent years held 500 pairs (Stavropol region 2006, L. Malovichko in litt. 2007) and 1,200 pairs (Orenburg province, Korshikov 2002). For Kazakhstan, Dolgushin (1962) mentions colonies of 'few, dozens, hundreds and sometimes thousands of pairs'. During the last 1o years no colonies larger than 100 pairs have been reported, except one colony of 600 pairs on the shore of the Caspian Sea near Atyrau in 2003 (S. Erokhov in litt. 2008).

There is no published information on the level of productivity that is required to maintain population stability in pratincoles. Lysenko (1980) found 50\% nest loss and 30\% chick loss caused by livestock trampling for breeding colonies in Ukraine. For the Collared Pratincole Glareola pratincola, Calvo (1994) found high hatching rates in marshland colonies $(88 \%$ of clutches hatched), but lower rates on farmland (29\% hatched). Belik and Lebedeva (2004) and Belik (2004) suggest both nest failure and chick mortality to reach 60-100\% in Black-winged Pratincole annually, but this is based on a study of 'colonial waders' in Central Kazakhstan and does not necessarily concern Black-winged Pratincole (Elkin 1981). Productivity of 1.30 chicks per pair in 2006 (Central Kazakhstan) exceeds that required by well-studied species, such as Northern Lapwing Vanellus vanellus (where $0.72-0.84$ chicks per female need to be produced

Table 1. Variables examined with logistic regression for an influence in Black-winged Pratincole habitat selection. $P$ values, measures of model fit and response direction for all univariate logistic regression models are given.

\begin{tabular}{llllll}
\hline Variable & $P$ & $R_{N}^{2}$ & AUC & Cohen's $\kappa$ & response shape \\
\hline maximum vegetation height & $<$ o.0001 & 0.653 & 0.960 & 0.770 & unimodal \\
distance to nearest permanent water feature & $<0.0001$ & 0.635 & 0.928 & 0.701 & sigmoid negative \\
distance to nearest settlement & $<$ o.0001 & 0.452 & 0.872 & 0.632 & sigmoid negative \\
\hline
\end{tabular}


distance to nearest permanent water feature

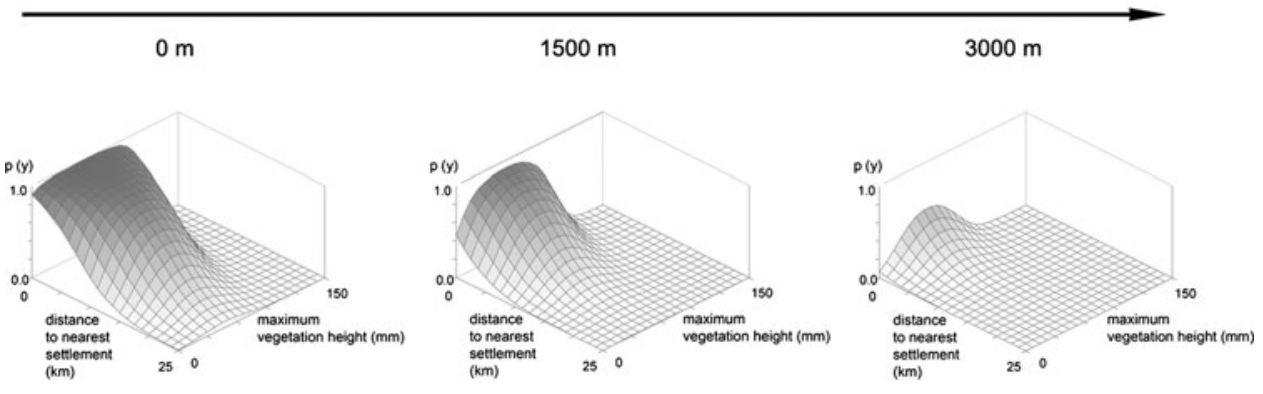

Figure 4. Multivariate habitat model including all three recorded habitat variables. Occurrence probability $(P)$ is plotted against 'distance to nearest settlement' and 'maximum vegetation height'. Diagrams represent different stages of the distance to water features.

annually to maintain population stability, Catchpole et al. 1999). Productivity of 0.59 chicks per pair as observed in 2007 in NE Kazakhstan is probably below this level. It is not clear why the level of productivity differs between the two study areas or years, but it may be linked to a difference in predation rates due to a shortage of voles in 2007 leading to an increase in predation by small carnivores (R.D.S. 2007 unpubl. data). Moseikin et al. (2004) found 100\% clutch loss after agricultural operations on arable land with four nesting colonies comprising a total of 61o pairs. This seems not to be an exception, as in our Lower Irtysh study area a colony of 30 pairs was extirpated by harrowing just after colony initiation. However, birds failing early in the breeding period could move to other sites and initiate replacement clutches.

\section{Habitat use and selection}

As habitat selection is a hierarchical process of behavioural responses, neither proximate nor ultimate factors can be determined by simply studying current bird distributions (Jones 2001). The results presented can provide only hints to this process. Our analysis quantified the high importance of livestock grazing and the availability of water in habitat selection, and suggests a preference for a distinct vegetation height, at least for the Central Kazakhstan population.

Suitable habitats were selected more often close to water, which might be due to the availability of drinking water for adults (Dolgushin 1962). Occurrence probability approached zero already $3 \mathrm{~km}$ from permanent water features in the Central Kazakhstan study area suggesting Blackwinged Pratincoles in steppe areas are dependent on the proximity to wetlands.

Obviously, an important proximate factor in habitat selection of Black-winged Pratincole is the presence and density of grazing livestock, suggested by the fact that short-grazed areas close to human settlements were preferred. However, solonchaks with Salicornia cover and muddy (salt and freshwater) lake shores produce a suitable vegetation height for natural reasons (hydrological conditions, salt dynamics). These areas are frequented by livestock mainly for resting and drinking, which leads to high dung densities. Dung might increase food abundance (coprophagous insects around dung piles and Diptera attracted to grazers), as birds have been seen pecking dung beetles from fresh and decaying dung piles (J.K. pers. obs., Atkinson et al. 2004). As clutches are often embedded in dung piles, other hypotheses include a possible heating effect of decaying dung, use of dung piles as orientation marks to facilitate recovery of own clutches in a colony environment, and, most likely, a camouflage effect of dung piles on embedded clutches. 
Table 2. Overview of recent large scale surveys for Black-winged Pratincole. 'pairs min.' refers to minimum number of breeding pairs counted/estimated, 'pairs max.' means estimated maximum numbers.

\begin{tabular}{|c|c|c|c|c|c|c|c|c|}
\hline & area & Source & $\begin{array}{l}\text { survey } \\
\text { year }\end{array}$ & $\begin{array}{l}\text { area size } \\
\left(\mathrm{km}^{2}\right)\end{array}$ & $\begin{array}{l}\text { pairs } \\
\text { min }\end{array}$ & $\begin{array}{l}\text { pairs } \\
\max \end{array}$ & $\begin{array}{l}\text { density } \\
\text { min }(\mathrm{BP} \\
\left.\text { 1ookm }^{-2}\right)\end{array}$ & $\begin{array}{l}\text { density } \\
\max (\mathrm{BP} \\
\text { Iookm }^{-2} \text { ) }\end{array}$ \\
\hline 1 & $\begin{array}{l}\text { Korgalzhyn, } \\
\text { Central Kazakhstan }\end{array}$ & $\begin{array}{l}\text { Kamp et al. } \\
\text { (this paper) }\end{array}$ & 2006 & 31,800 & 1,207 & 1,500 & 3.80 & $4 \cdot 72$ \\
\hline 2 & $\begin{array}{l}\text { Lower Irtysh, } \\
\text { NE Kazakhstan }\end{array}$ & $\begin{array}{l}\text { Kamp et al. } \\
\text { (this paper) }\end{array}$ & 2007 & 12,000 & 627 & 785 & 5.23 & 6.54 \\
\hline 3 & $\begin{array}{l}\text { Naurzum reserve, } \\
\text { W Kazakhstan }\end{array}$ & Bragin 2004 & 2004 & 12,000 & 429 & 586 & 3.58 & 4.88 \\
\hline 4 & $\begin{array}{l}\text { Chelyabinskaya oblast', } \\
\text { S Central Russia }\end{array}$ & $\begin{array}{l}\text { Karyakin \& } \\
\text { Koslov } 1999\end{array}$ & 1999 & 87,000 & 2,000 & 4,000 & 2.30 & 4.60 \\
\hline 5 & $\begin{array}{l}\text { Orenburgskaya oblast', } \\
\text { S Central Russia }\end{array}$ & Korshikov 2002 & 1999 & 40,000 & 2,500 & 2,500 & 6.25 & 6.25 \\
\hline 6 & $\begin{array}{l}\text { Stavropolskii Krai, } \\
\text { SW European Russia }\end{array}$ & $\begin{array}{l}\text { L. Malovichko in } \\
\text { litt. } 2007\end{array}$ & 2006 & 66,500 & 1,800 & 1,800 & 2.71 & 2.71 \\
\hline
\end{tabular}

\section{Population numbers}

We estimated the world population to approximately $76,000-95,000$ breeding pairs, equalling 152,000-190,000 mature individuals. This estimate is significantly higher than the latest estimate of 29,000-45,000 mature individuals (BirdLife International 2007), which was largely based on 'best guess' for the Asian part of the distribution area (V.V. Khrokov pers. comm. 2006). The new population estimate is supported by a recent count from a single site on the wintering grounds: 76,500 birds were present at Vaal Dam, South Africa, in 2006 (University of Cape Town 2006). In 1991, an even larger flock of 250,000 to 800,000 birds was observed in Orange Free State, South Africa (du Plessis 1995). A post-breeding flock of 20,000 birds at Manych wetlands, SW Russia in September 2006 (M.A.K. 2006 unpubl. data) indicates higher numbers in European Russia.

Pratincoles are known to exhibit a sporadic distribution pattern, i.e. the distribution and size of colonies vary noticeably between years (Belik 2004). As we used data from different areas and different years, our population estimate might be biased upwards, assuming that birds from a study area surveyed early abandoned it and then moved to another that was surveyed subsequently. However, given the background of the recent high counts on passage and in the wintering areas, and because all surveyed areas are quite distant from each other, we regard it as unlikely that the new estimate is strongly biased due to this reason.

\section{Population trends in the light of changing steppe land use and habitat availability}

Land use changed significantly across the Eurasian steppe belt within the last 100 years. The steppes of Ukraine and European Russia had been ploughed almost completely by 1900, whereas in Asian Russia and Kazakhstan, the proportion of arable land was negligible until the 1950s and grazing by domestic animals was the most widespread type of land use. After the Second World War, the 'Virgin Lands Campaign' of the Soviet government heavily affected the steppe ecosystem: Between 1953 and 1961, 41.7 million hectares (25.4 million ha in Kazakhstan) of steppe were ploughed, mainly for wheat cultivation (Wein 1983).

Livestock numbers were high in Kazakhstan until the 1930s (an estimated 150 million livestock units [LU] in 1930; Robinson and Milner-Gulland 2003), but crashed then due to the rigorous 
enforcement of the Soviet collectivisation policy and the resulting emigration of over one million nomads (around 14\% of the population) to China and Mongolia (only 25 million LU left by 1935). From 1950 to 1991, livestock numbers increased steadily, reaching 100 million LU at the end of the Virgin Lands Campaign, and were back to the level of the 193 os by 1990 (Robinson and Milner-Gulland 2003).

After the collapse of the Soviet Union in 1991, institutional changes led to the end of the state crop subsidy system. This resulted in large-scale abandonment of arable fields across Kazakhstan (De Beurs and Henebry 2004). The area sown for crops in Kazakhstan was reduced by $38 \%$ through the mid-1990s (Suleimenov \& Oram 2000). In the Korgalzhyn study area, even 60-80\% of all formerly agriculturally used area fell fallow between 1991 and 1998 (own analysis from Landsat 7 ETM+ imagery). Livestock numbers both in Russia and Kazakhstan crashed after the collapse of the Soviet Union due to the withdrawal of state support and the use of animals as currency. In all Russian steppe regions combined, total livestock numbers (cattle, horses, sheep and goats) decreased by $49 \%$ (GosKomStat 2001). In Kazakhstan, the political and economical changes affected livestock numbers as well, resulting in a decline of $58 \%$ in cattle and $75 \%$ in sheep and goats from 1990 to 1999 (Suleimenov and Oram 2000, Robinson and Milner-Gulland 2003). These figures are fairly representative for our study areas, as outlined by Lenk (2001). Since about 2002, livestock numbers have been increasing again by approximately $10 \%$ in our study areas (J.K. 2008, unpubl. data).

Our study revealed that Black-winged Pratincole is largely dependent on the presence of large grazers. Although precise figures on population trends are lacking, there is evidence that population development (overview in Belik 2004, Belik and Lebedeva 2004) is at least partly a function of habitat availability: Declines occurring from the end of the 19th century in Ukraine and European Russia have been associated with the increase in ploughed area and a loss of grazed steppe. A further rapid decrease recorded in the 1950 os was probably related to massive habitat loss during steppe ploughing under the Virgin Lands Campaign. A stable and locally positive trend in numbers during the Soviet period until the 1990s might have been linked to then increasing livestock numbers, as well as the sudden decline by $40-60 \%$ (Belik 2004) in the 1990s going along with a crash in livestock numbers, the latter causing former pastures to be overgrown with dense, weedy vegetation.

There is evidence that the large decline of pratincoles described for the second half of the 2oth century has halted now in larger parts of the range east of the Ukraine. L. Malovichko (in litt. 2007, Table 2) counted 1,800 breeding pairs in an area in European Russia in 2006, where only 100-200 were estimated in 2002 (Belik 2004). Karyakin and Koslov (1999) noticed an increase in numbers in southern Russia after a pronounced decline during the Soviet era. Korshikov (2002) revealed higher numbers compared to Soviet times numbers in a south Russian stronghold, and there is evidence that in central and northeastern Kazakhstan the number of pratincoles has increased by $20-30 \%$ between 1998 and 2007 (A.V. Koshkin pers. comm. 2007, A.O. Solomatin pers. comm. 2007).

This increase coincides with the massive increase of fallow and abandoned land described above, and indeed, $25 \%$ of all breeding pairs in NE Kazakhstan (this study), and $40 \%$ of the breeding pairs found by L. Malovichko (in litt. 2007; Table 2) in European Russia nested on fallow and abandoned land.

However, former arable areas are only suitable habitats for Black-winged Pratincoles during the first years after abandonment, as the vegetation of mainly weedy species tends to get too tall and dense if not grazed constantly, so pratincoles might not benefit from these areas in the long term.

Changing grazing patterns might have influenced pratincole numbers as well. Whereas during the Soviet era total livestock numbers were an order of magnitude higher than today, overall grazing pressure was probably less. The animals were driven further away from settlements and state farms, in order to avoid overgrazing and simply because arable fields started mostly right at the edges of villages (Robinson et al. 2003).

Since privatisation of the livestock sector in the 1990s, people tend to keep the herds in close vicinity of settlements for logistical reasons. The migration of stock to summer pastures across 
the steppe belt has ceased due to a lack of transport facilities. In localized areas, this leads to much higher grazing pressure than in Soviet times, turning former tall grassland, fallow hay and wheat fields into short-grazed swards. These areas are used by a large proportion of the pratincoles in our study areas (see Results).

Apart from habitat availability, there might by other threats to the species (see Introduction). Farming intensity is still high in some areas of Russia and across Ukraine, so arable fields might function as 'ecological traps', i.e. attract pratincoles to breed, but weaken the population due to low breeding success (Moseikin et al. 2004). However, it is not clear to what extent arable fields attract pratincoles for breeding as these are difficult to survey. In both our study areas they were used by a minor proportion of the population.

Trampling of clutches at the strongly grazed areas around settlements might be a problem, and sheep flocks driven at speed through colonies can cause significant clutch loss (J.K. 2007 unpubl. data; see also Watson et al. 2006 for the ecologically close Sociable Lapwing Vanellus gregarius). However, the comparatively high fledging rates revealed in our study indicate that trampling might be less of an issue than expected.

\section{Implications for conservation}

As described above, the decline of Black-winged Pratincole numbers was apparently not as dramatic as suggested by Belik and Lebedeva (2004), and the world population seems to be substantially larger than previously thought. Habitat availability seems to have increased during recent years. However, there is no doubt that especially in the European parts of the range the species has decreased significantly in numbers. A range contraction and increasing isolation of breeding areas has occurred, and the species might have recently become extinct in Ukraine.

As the Black-winged Pratincole remains understudied, we suggest a focus on research at the breeding grounds on

i) the current distribution and numbers at the edges of the species' range (SW Russia, Ukraine, E Kazakhstan),

ii) past and likely future land use and habitat changes across both the breeding and wintering range and their effect on population development

iii) the level of productivity and reasons for clutch loss as well as chick mortality in different habitats (especially whether arable fields function as ecological sinks),

To reduce the risk of trampling by livestock, an approach that takes into consideration rural communities is much needed. Talking to shepherds and suggesting they avoid the colony areas might help to increase breeding success. If trampling is an issue, fencing colonies might be an option. In Russia, Sociable Lapwing clutches on arable land hatched successfully, when conservationists informed farmers and solicited the exclusion of the colony area from harrowing (Morozov 2005).

\section{Acknowledgements}

Fieldwork was funded by the UK government's Darwin Initiative and the Royal Society for the Protection of Birds (RSPB) in the framework of the International Sociable Lapwing Research and Conservation project under the auspices of BirdLife International. JK received additional funding from the German Academic Exchange Service (DAAD), grant No. D 06-41-303, and 'Foerderkreis fuer allgemeine Biologie/Naturkunde' (FAN-B). We thank Kseniya V. Grishina, Madina Makhmetova, Albert Salemgareev, Paul Eele and John Wills for support during fieldwork. Dr. Robert Biedermann and Dr. Barbara Strauss gave important support in data analysis. Dr. Paul Donald, Holger Schielzeth and two anonymous referees kindly reviewed and improved the manuscript. 


\section{References}

Atkinson, P. W., Buckingham, D. M. and Antony, J. (2004) What factors determine where invertebrate-feeding birds forage in dry agricultural grasslands? Ibis 146: 99-107.

Austin, M. P. (2002) Spatial prediction of species distribution: an interface between ecological theory and statistical modelling. Ecol. Modell. 157: 101-118.

Belik, V. P. (2004) Black-winged Pratincole: distribution, ecology, limiting factors. Strepet 2: 68-100. (In Russian.)

Belik, V. P. and Lebedeva, E. A. (2004) International single species action plan for the conservation of the Black-winged Pratincole Glareola nordmanni. Bonn: AEWA technical series No.4.

Belik, V. P., Babich, M. V. and Korenev, P. I. (2000) Catastrophic declines in Blackwinged Pratincole (Glareola nordmanni) numbers north of the Caucasus. Inf. Materials Russ. Wader Study Group 13: 36-38. (In Russian, English summary.)

BirdLife International (2004) Birds in Europe population estimates, trends and conservation status. Cambridge, UK: BirdLife International.

BirdLife International (2007) The world Red Data Book of birds - update 2007. http://www. birdlife.org/datazone/species/index.html? action $=$ SpcHTMDetails.asp\&sid $=3189 \&$ $\mathrm{m}=\mathrm{O}$, accessed February 2008.

Bonn, A. and Schröder, B. (2001) Habitat models and their transfer for single and multi species groups: a case study of carabids in an alluvial forest. Ecography 24: 483-496.

Calvo, B. (1994) Effects of agricultural landuse on the breeding of Collared Pratincole Glareola pratincola in south-west Spain. Biol. Conserv. 70: 77-83.

Catchpole, E. A., Morgan, B. J. T., Freeman, S. N. and Peach, W. J. (1999) Modelling the survival of British Lapwings Vanellus vanellus using ring-recovery data and weather covariates. Bird Study 46 (Suppl): 5-13.

Davygora, A. V., Kornev, S. V., Glavnyuk, E. V. and Korshikov, L. V. (1992) Current status and conservation of waterbirds in the Southern Ural steppe zone. Pp. 33-40 in Rare plants and animals of the Oren- burg province. Orenburg, Russia. (In Russian.)

De Beurs, K. M. and Henebry, G. M. (2004) Land surface phenology, climatic variation, and institutional change: analyzing agricultural land cover change in Kazakhstan. Remote Sens. Environ. 89: 497-509.

Dolgushin, I. A. (1962) Birds of Kazakhstan, Vol.3. Alma-Ata: Academy of Sciences of the Kazakh SSR. (In Russian.)

du Plessis, G. J. (1995) Large aggregation of Black-winged Pratincoles Glareola nordmanni in the northern Orange Free State. Ostrich 66: 40-41.

Elkin, K. F. (1981) Livestock herding and survival of breeding waders in Northern Kazakhstan. Pp. 49-51 in Scientific basics of colonial waterbird research. Moscow: Nauka. (In Russian.)

GosKomStat (2001) Livestock inventories by region, Russia, January 1, 1991-2000. http://www.ers.usda.gov/Briefing/Russia/ Data/LivestockInventoriesByRegion.xls. Accessed February 2008.

Graham, M. (2003) Confronting multicollinearity in ecological multiple regression. Ecology 84: 2809-2815.

Hanley, J. (1982) The meaning and use of the area under a receiver operating characteristic (ROC) curve. Radiology 143: 29-36.

Hosmer, D. and Lemeshow, S. (2000) Applied logistic regression. New York: Wiley.

Jacobs, J. (1974): Quantitative measurement of food selection. Oecologia 14: 413-417.

Jenness, J. (2005) Random point generator (randpts.avx) extension for ArcView 3.x. http://www.jennessent.com/arcview/random_ points.htm, accessed February 2008.

Jones, J. (2001) Habitat selection studies in avian ecology: a critical review. Auk 118: 557-562.

Karyakin, I. V. and Koslov, A. A. (1999) Black-winged Pratincole (Glareola nordmanni). Pp. $182-183$ in I. V. Karyakin and A. A. Koslov, eds. Preliminary distribution atlas of the birds of Chelyabinsk Province. Novosibirsk, Russia. (In Russian.)

Kessler, K. (1851) Natural history of the Kiev province: zoology, systematic part. Kiev: 
Komissiya dlya opisaniya gubernii Kievskogo uchebnago okruga. (In Russian.).

Korshikov, L. V. (2002) Black-winged Pratincole Glareola nordmanni in the steppes of Orenburg province: survey results and current population status. Pp. $35-38$ in A. O. Shubin and P. S. Tomkovich, eds. Waders of Eastern Europe and Northern Asia at the turn of the century - conference proceedings. Moscow: Moscow Pedagogical State University. (In Russian.)

Koshelev, A. I. (1983) The Black-winged Pratincole Glareola nordmanni in Southern Baraba Steppe, Western Siberia. Priroda 9: 40-42. (In Russian.)

Lenk, M. (2001) Socio-economic transformation processes in rural Central Kazakhstan after the country's independence in 1991. Diploma thesis. Ernst Moritz Arndt University, Greifswald, Germany (In German.)

Lysenko, V. I. (1980) Conservation of waders in Zaporozh'e province, Ukraine. Pp. 67-68 in New developments in research on biology and distribution of waders in Russia. Moscow: Nauka. (In Russian.)

Manel, S., Williams, H. C. and Ormerod, S. J. (2001) Evaluating presence-absence models in ecology: the need to account for prevalence. J. Appl. Ecol. 38: 921-931.

Manly, B. F. J. (2001) Randomization, bootstrap and Monte Carlo methods in biology. London: Chapman and Hall.

McNeil, B. and Hanley, J. (1984) Statistical approaches to the analysis of receiver operating characteristic (ROC) curves. Med. Decis. Making 4: 137-150.

Morozov, V. V. (2005) Sociable Plover surveys in steppes of Southern Russia 2005. Unpublished report. Moscow and Cambridge: BirdLife International.

Moseikin, V. N., Malovichko, L. V. and Fedosov, V. N. (2004) Agriculture threatens the population of the Black-winged Pratincole Glareola nordmanni in European Russia. Inf. Materials Russ. Wader Study Group 17: 30-34. (In Russian.)
Nagelkerke, N. (1991) A note on a general definition of the coefficient of determination. Biometrika 78: 691-692.

Robinson, S. and Milner-Gulland, E. J. (2003). Political change and factors limiting numbers of wild and domestic ungulates in Kazakhstan. Human Ecol. 31: 87-110.

Robinson, S., Milner-Gulland, E. J. and Alimaev, I. (2003) Rangeland degradation in Kazakhstan during the Soviet Era: re-examining the evidence. J. Arid Environ. 53: 419-439

Samorodov, Y. A. (1986) Numbers, phenology and distribution of Glareolidae species at the north-west of the Caspian Sea. Pp. 70-73 in Terrestrial and aquatic ecosystems. Gorkii: All-university Publishers. (In Russian.) Schielzeth, H., Eichhorn, G., Heinecke, T., Kamp, J., Koshkin, M. A., Koshkin, A. V. and Lachmann, L. (2008) Waterbird population estimates for a key staging site in Kazakhstan: a contribution to wetland conservation on the Central Asian flyway. Bird Conserv. Internatn. 18: 71-86.

Strauss, B. and Biedermann, R. (2006) Urban brownfields as temporary habitats: Driving forces for the diversity of phytophagous insects. Ecography 29: 928-940.

Suleimenov, M. and Oram, P. (200o) Trends in feed, livestock production, and rangelands during the transition period in three Central Asian countries. Food Policy 25: 681-700.

University of Cape Town (2006) Citizen science, again...: coordinated waterbird counts in South Africa. Cape Town, South Africa: Report of the Avian Demography Unit, University of Cape Town.

Watson, M., Wilson, J. M., Koshkin, M., Shcherbakov, B., Karpov, F., Gavrilov, A., Schielzeth, H., Brombacher, M., Collar, N. J. and Cresswell, W. (2006). Nest survival and productivity of the critically endangered Sociable Lapwing Vanellus gregarius. Ibis 148: 489-502.

Wein, N (1983) Die Sowjetunion. Paderborn: UTB/Schoeningh. 
JOHANNES KAMP*, ROBERT D. SHELDON

The Royal Society for the Protection of Birds, The Lodge, Sandy, Bedfordshire SG19 2DL, U.K.

MAXIM A. KOSHKIN

Association for the Conservation of Biodiversity in Kazakhstan, ul. Beibitshilik, 18, office 203, o10oo Astana, Republic of Kazakhstan.

*Author for correspondence; e-mail: johannes.kamp@rspb.org.uk

Received 20 March 2008; revision accepted 27 August 2008 